Vol.2 No.1, Agustus 2019

\title{
RANCANG BANGUN SISTEM INFORMASI ADMINISTRASI TAHANAN DAN BARANG BUKTI MENGGUNAKAN MODEL PROTOTYPE PADA KEPOLISIAN DAERAH JAMBI
}

\author{
Tisya Qintari Fadillah ${ }^{1)}$, Tri Suratno ${ }^{2)}$, dan Mauladi ${ }^{3)}$ \\ ${ }^{1)}$ Fakultas Sains dan Teknologi, Universitas Jambi \\ Email: tisyaqintarifadillah@gmail.com \\ ${ }^{2)}$ Fakultas Sains dan Teknologi, Universitas Jambi \\ Email: tri@unja.ac.id \\ ${ }^{3)}$ Fakultas Sains dan Teknologi, Universitas Jambi \\ Email: mauladi@unja.ac.id
}

\begin{abstract}
The process of administering detainees and evidence managed by the Directorate of Detention and Evidence in the Jambi Regional Police which is currently underway is considered to be less effective and efficient because there are still some shortcomings that could have an impact in the future. These deficiencies can interfere with the administrative process of detainees and evidence that should run optimally in the future. Therefore this research was conducted to provide solutions to these problems by developing a new information system that can overcome and deal with the various shortcomings that occur today. The information system development method used in this study is design and creation using the prototype method. The prototype method consists of 5 stages: communication, quick plan, modeling quick design, contruction of prototype and deployment, delivery and feedback. In addition, the system that has been built will be functionally tested using black box testing. This test is conducted as a trial method that focuses on finding input conditions errors in the system. The results of the study using black box testing using 55 points of the test scenario show that this system is functionally running optimally.
\end{abstract}

Keywords: Information System, Prototype, Black Box Testing

\section{PENDAHULUAN}

Kepolisian Daerah merupakan satuan pelaksana utama kewilayahan yang berada dibawah Kapolri. Polda bertugas menyelenggarakan tugas Polri pada tingkat kewilayahan. Polda dipimpin oleh Kapolda (Kepala Kepolisian Negara Republik Indonesia Daerah) yang bertanggung jawab kepada Kapolri. Dalam melaksanakan tugasnya, POLDA tidak terlepas dari pengelolaan tahanan dan barang bukti. Kegiatan pengelolaan tahanan dan barang bukti terletak dibawah naungan direktorat tahanan dan barang bukti.
Pada saat ini proses administrasi tahanan dan barang bukti dilakukan secara manual menggunakan aplikasi microsoft excel sedangkan untuk beberapa persuratan dan laporan tahanan serta barang buktinya menggunakan aplikasi microsoft word. Pembuatan laporan dan catatan tersebut disimpan kedalam berbagai tempat yang berbeda tanpa adanya integrasi antar komputer. Dengan prosedur yang dijalani secara stand alone selama ini membuat proses pencatatan berjalan kurang efektif dan efisien dikarenakan pencatatan yang terpisah-pisah dengan jumlah tahanan yang tidak sedikit. Dari sisi pengolahan data, meskipun 
Vol.2 No.1, Agustus 2019

masukan data telah menggunakan aplikasi pada komputer, namun prosedur operasional tahanan masih berjalan secara manual dengan mengirimkan berkas dari satu staff ke staff lainnya. Menelaah dari prosedur yang sedang dijalani, proses pengolahan serta pencatatan data dapat menimbulkan berbagai kesalahan dan resiko diantaranya data yang mudah hilang, kesalahan pengetikan serta redundansi data. Hal ini dapat berakibat dibutuhkannya waktu ekstra untuk memanipulasi data karena akan membutuhann waktu yang cukup banyak untuk membuat serta melaporkan laporan yang sebelumnya sudah pernah ada.

Berdasarkan permasalahan yang dihadapi, permasalahan-permasalahan yang dihadapi tersebut dapat diatasi dengan sebuah sistem informasi yang realtime dan relevan serta mampu melakukan proses penambahan data, pencarian dan manajemen laporan yang akurat yang pada akhirnya informasi tersebut dapat digunakan untuk mengambil keputusan oleh pihak yang berwenang. selanjutnya rancang bangun aplikasi ini menggunakan model prototype yang terdiri atas 5 tahapan, yaitu quick plan, modelling quick design, contruction of prototype dan deployment, delivery and feedback. Model Prototype merupakan teknik pengembangan sistem yang menggunakan prototype sistem untuk menggambarkan sistem, sehingga pengguna atau pemilik sistem mempuyai gambaran pengembangan sistem yang akan dilakukan(Mulyani, 2016).
Selanjutnya, sistem informasi yang sudah dibuat juga harus diuji untuk mengetahui apakah sistem tersebut dapat berjalan sesuai dengan apa yang diharapkan. Oleh karena itu peneliti menggunakan pengujian black box. Black boxtesting berfokus pada spesifikasi fungsional dari perangkat lunak. Pengujian fungsionalitas adalah pengujian perangkat lunak yang diuji untuk persyaratan fungsional. Pengujian dilakukan dalam bentuk tertulis apakah aplikasi berjalan seperti yang diharapkan(Simarmata, 2010). Pengujian black box cenderung untuk menemukan hal-hal berikut(Mustaqbal et al,2015):

a. Fungsi yang tidak benar atau tidak ada,

b. Kesalahan antarmuka(interface errors),

c. Kesalahan pada struktur data dan akses baris data,

d. Kesalahan performansi(performance errors), dan

e. Kesalahan inisialisasi dan terminiasi.

\section{METODE PENELITIAN}

\section{Alat dan Bahan}

Alat yang digunakan dalam penelitian ini terdiri atas perangkat keras berupa laptop dengan spesifikasi RAM 2 GB dan perangkat lunak berupa OS Windows 10, web browser Google Chrome 74.0.3, server apache XAMPP 3.2.2, PHP 5.7.12, MySQL 10.1.33, Pencil 3.0.4, Microsoft Visio 2013 serta text editorSublime Text. Bahan yang digunakan pada penelitian ini terdiri atas data tahanan dan barang bukti Polda Jambi tahun 2017, hasil 
Vol.2 No.1, Agustus 2019

diskusi dengan pihak DIT TAHTI Polda Jambi serta hasil pengujian black box testing.

\section{Metode Pengumpulan Data}

Pengumpulan data dalam penelitian ini dilakukan dengan observasi objek penelitian, diskusi serta studi pustaka yang digunakan sebagai teori pendukung dalam penelitian dan kuisioner untuk melakukan pengujian terhadap sistem informasi.

\section{Model Pengembangan Sistem}

Model pengembangan yang digunakan dalam penelitian ini adalah model prototype. Dalam penelitiannya, Sabale(2012) menyatakan model prototype menempatkan lebih banyak keterlibatan pengguna untuk memberikan umpan balik terhadap program dimulai dari perencanaan awal dan berakhir dengan interaksi diantara keduanya. Pressman(2015) menjelaskan model prototype kedalam beberapa tahapan sebagai berikut.

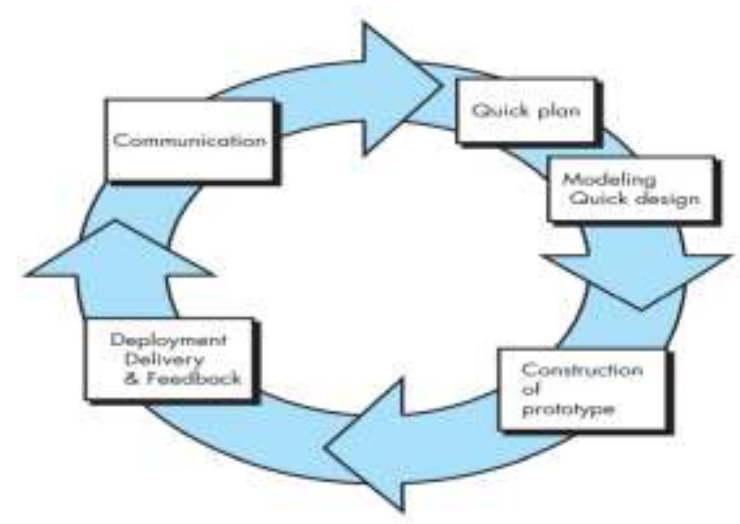

Gambar 1. Model Prototype

Penjelasan dari gambar diatas adalah sebagai berikut.

\section{Communication}

Merupakan tahapan komunikasi awal dengan user mengenai program yang akan dibuat. Dalam hal ini meliputi analisa sistem administrasi tahanan dan barang bukti yang berjalan saat ini, serta mengidentifikasi permasalahan yang terjadi dalam proses manual tersebut.

\section{Quick Plan}

Merupakan tahapan dimana peneliti melakukan perencanaan strategis secara cepat dengan memberikan solusi atas identifikasi awal. Dalam penelitian ini, peneliti memberikasikan sebuah sistem usulan berupa flowchart dari sebuah sistem informasi administrasi tahanan dan barang bukti yang lebih efisien.

\section{Modeling Quick Design}

Merupakan tahapan melakukan desain sistem. Dalam penelitian ini dilakukan iterasi yang digambarkan pada gambar berikut ini.

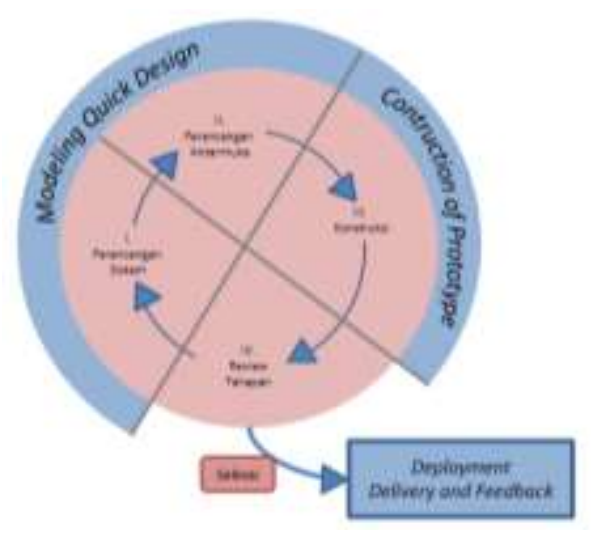

Gambar 2. Tahapan Iterasi pada Tahap Modeling Quick Design

\section{Contruction of Prototype}


Vol.2 No.1, Agustus 2019

Tahapan ini merupakan tahapan dimana semua rencana dan perancangan yang telah dilakukan diimplementasikan kedalam Bahasa pemrograman. Pada tahapan ini juga dilakukan perancangan database berdasarkan class diagram yang telah dibuat.

\section{Deployment, Delivery and} Feedback

Pada tahapan ini, program yang telah dibuat dilakukan pengujian untuk menguji fungsionalitas dari sistem yang dibuat. Pada penelitian ini, peneliti menggunakan pengujian black box yang befokus pada fungsionalitas sistem.

\section{Pengujian Black Box}

Pengujian didalam penelitian ini menggunakan black box testing. Pengujian black box bertujuan untuk menguji sebuah sistem informasi yang berfokus pada functionality saja. Penggunaan black box testing dilakukan dengan menggunakan beberapa kasus uji berupa data benar dan data salah beserta hasil yang diharapkan.

\section{HASIL DAN PEMBAHASAN}

\section{Communication}

a. Analisis Sistem yang Berjalan

Proses administrasi tahanan dan barang bukti yang berjalan saat ini dimulai dari masuknya surat pengantar dari direktorat kerja lainnya. Direktorat kerja tersebut mengantar surat pengantar tersebut beserta tahanan ke DIT TAHTI untuk ditindaklanjuti hingga kepersidangan. Surat tersebut memuat nomor surat dan kasus yang diduga dilakukan oleh tahanan yang kemudian diserahkan ke unit kerja Pamtah. Unit kerja inilah yang menginput data tahanan menggunakan aplikasi Microsoft office meliputi nama, jenis kelamin, dasar penahanan serta pasal tahanan. Setelah proses admnistasi tahanan selesai, pihak pamtah berkoordinasi dengan unit barang bukti untuk mengelola data barang bukti setiap tahanan. Dan pada setiap bulannya, unit kerja pamtah dan barbuk melakukan penyerahan laporan kepada unit remin untuk dilakukan proses validasi data. Dan bila diterima, maka data tersebut akan menjadi sebuah laporan yang akan diketahu kasubdit.

Berdasarkan identifikasi awal, jarang sekali terjadi pengevaluasian kembali dikarenakan unit pamtah yang dianggap lebih mengetahui informasi tahanan. Meninjau dari evaluasi laporan pada tahun 2017 masih terdapat data tahanan yang bertumpuk didalam sebuah lapora yang sama penyebabnya yang dikarenakan human error.

b. Identifikasi Permasalahan

Berdasarkan identikasi awal yang dilakukan, berikut identikasi permasalahan yang disimpulkan:

1. Proses administrasi yang berjalan seperti penginputan data dan pelaporan yang berjalan manual rentan mengalami kesalahan penulisan dan kehilangan data. 
Vol.2 No.1, Agustus 2019

2. Keamanan data menggunakan aplikasi stand alone yang hanya mengandalkan backup ke flashdisk dianggap terlalu beresiko.

3. Proses pelaporan yang memakan waktu banyak dinilai kurang efektif dan efisien utuk mendapatkan laporan dalam waktu yang singkat dan data yang akurat.

4. Proses yang telah berjalan masih mengandalkan pengantaran berkas dari satu staff kestaff lainnya, sehingga hal ini bersifat tidak efektif.

5. Proses manualisasi yang berjalan dinilai belum mampu menjyajikan informasi yang aktual dan relevan serta terlepas dari data yang redundansi.

\section{Quick Plan}

Kegiatan pada tahapan ini adalah melakukan perencanaan secara cepat terhadap sistem yang diusulkan berdasarkan kebutuhan yang telah diidentifikasi sebelumnya. Perencanaan dalam tahapan ini adalah sebagai berikut.

1. Sistem yang akan dikembangkan berbasis web menggunakan bahasa pemrograman PHP dengan framework Laravel versi 5.7 yang berdiri diatas web server apache.

2. Sistem yang akan dikembangkan menggunakan database MySQL.

3. Menentukan pengguna didalam sistem, yaitu: 1) Admin, merupakan user yang mengelola sistem secara keseluruhan, 2) Staff Pamtah, merupakan user yang khusus mengelola bagian administrasi tahanan, 3) Staff Barbuk, merupakan user yang khusus mengelola bagian administrasi barang bukti, 4) Direktur, merupakan pengguna yang dapat melihat hasil akhir sistem berupa laporan, 5) Remin, merupakn user yang melakukan seleksi/ validasi terhadap aktivitas sistem ini.

4. Rancangan sistem yang diusulkan. Berikut diagram usulan yang dituangkan kedalam flowchart:

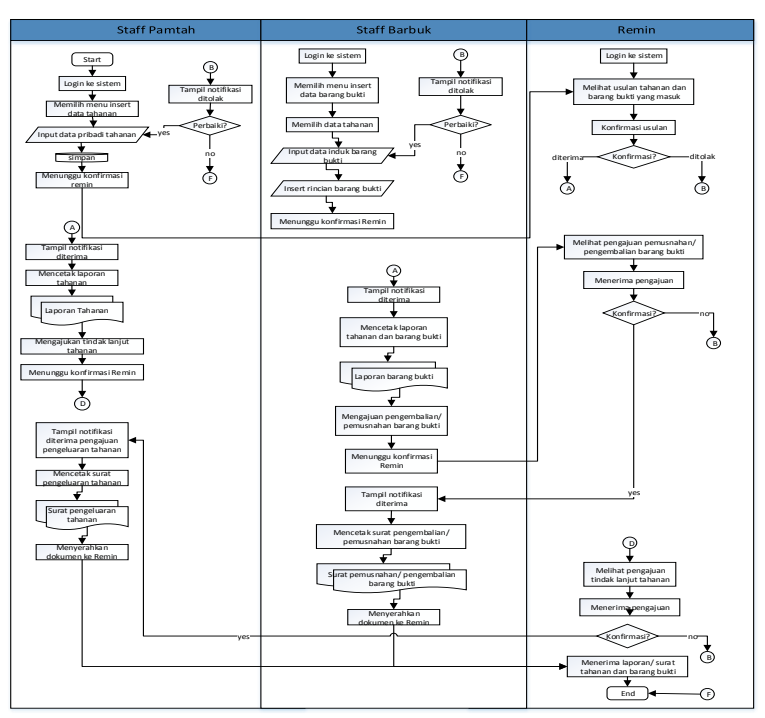

\section{Gambar 3. Flowchart Sistem Usulan}

\section{Modeling Quick Design}

Pada tahapan ini, beberapa hal yang dilakukan peneliti adalah sebagai berikut. 
Vol.2 No.1, Agustus 2019

1. Membuat use case diagram yang dapat dilihat pada Gambar 4, 5 dan 6.

2. Membuat Rancangan activity diagram, sequence diagram serta class diagram yang dapat dilihat pada Gambar 7.

3. Perancangan struktur menu sistem yang terdiri dari menu login,dashboard, data master yang terdiri atas data jenis tahanan, pasal, penerima, rujukan dan jabatan, data tahanan, data barang bukti, data pengeluaran tahanan, data pengembalian/ pemusnahan barang bukti, halaman validasi, serta log aktivitas sistem.

4. Perancangan user interface sebagai gambaran umum antar muka sistem yang akan dibuat. Perancangan user interface ini dibuat berdasarkan rancangan struktur menu yang telah dibuat sebelumnya.

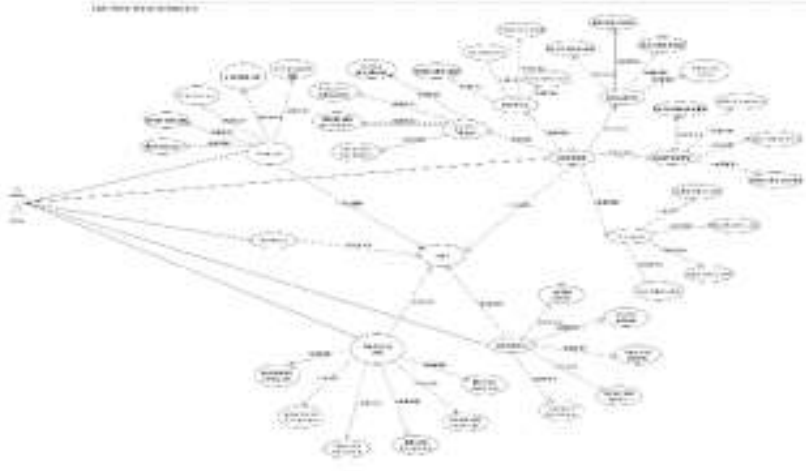

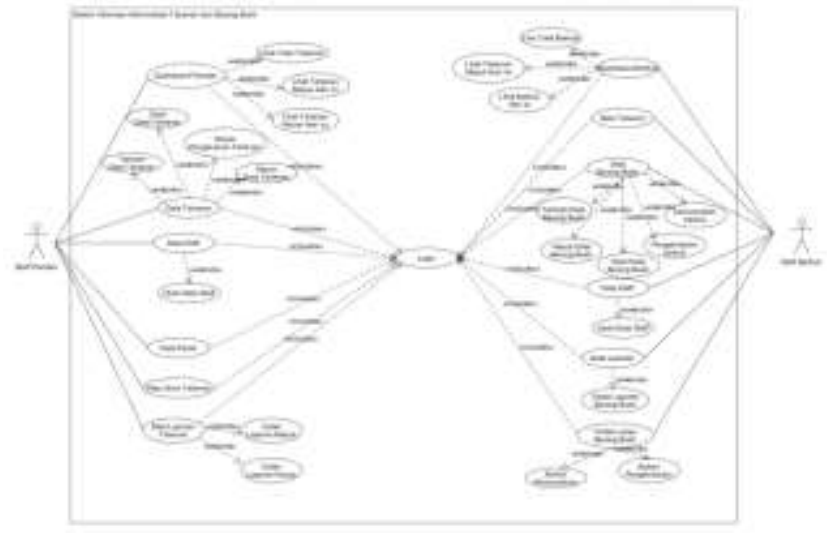

Gambar 4.Use Case Diagram Administrator

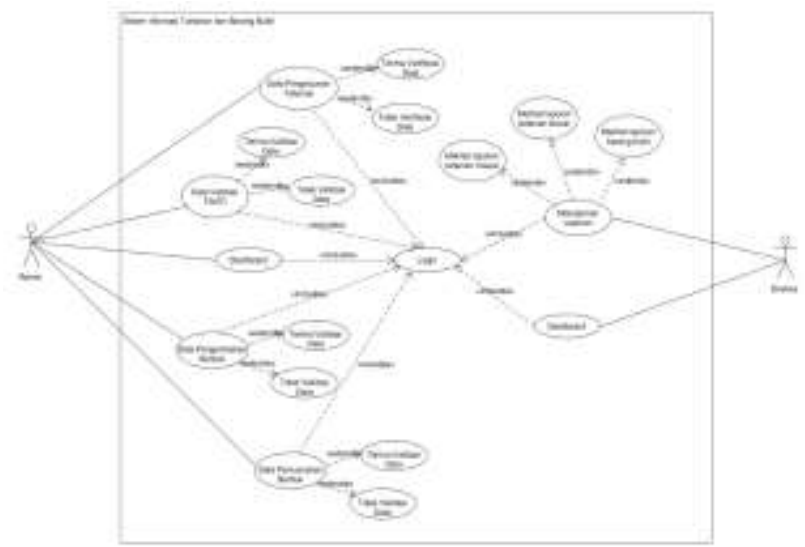

Gambar 5.Use Case Diagram Pamtah dan Barbuk

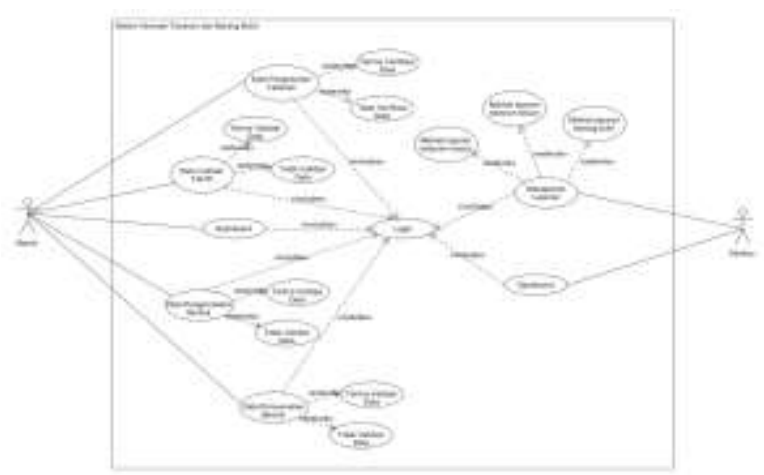

Gambar 6.Use Case Diagram Remind dan

Direktur 
Vol.2 No.1, Agustus 2019

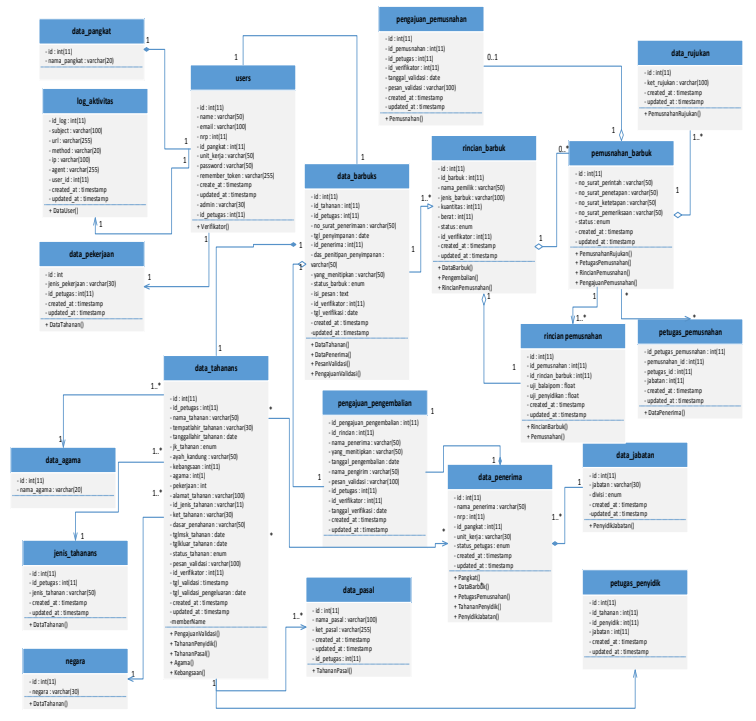

Gambar 7.Class Diagram

\section{Construction of Prototype}

Pada tahapan ini dilakukan pengkodean berdasarkan rancangan-rancangan yang telah dibuat. Pengkodean pada sistem ini menggunakan bahasa pemrograman PHP dengan menggunakan framework Laravel versi 5.7.12 dengan menggunakan beberapa library dari javascript yang dibutuhkan, dan menggunakan framework css bootstrap untuk memperindah tampilan antar muka. Selain itu pembangunan basis data pada aplikasi ini menggunakan software database MySQL dan proses menjalankannya menggunakan web browserGoogle Chrome.

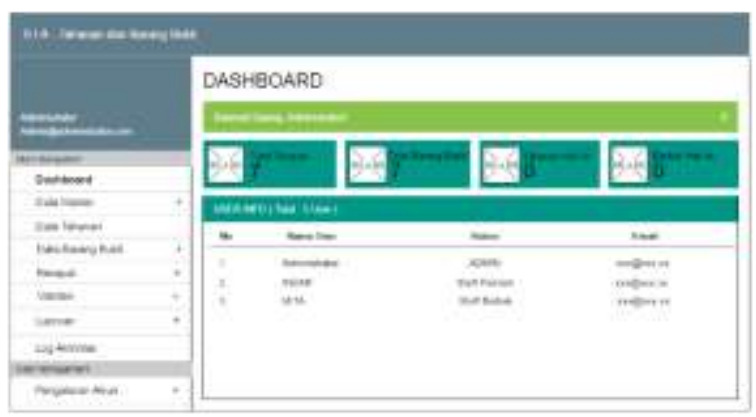

Gambar 8. Rancangan User Interface Dashboard pada Sistem

\section{Deployment, Delivery and Feedback}

Pada tahapan ini sistem yang telah dibangun, dilakukan pengujian untuk menguji sistem. Pengujian sistem yang telah dibuat menggunakan pengujian black box dengan 3 orang tester yang melakukan pengujian terhadap sistem. Pengujian black box digunakan dengan tujuan untuk menguji sistem menggunakan skenario uji untuk fungsi masukan guna mendapatkan jawaban apakah sistem yang dibangun telah sesuai dengan apa yang diharapkan. Dan berikut hasil pengujian black box pada sistem ini.

Tabel 1. Hasil Pengujian Black Box

\begin{tabular}{|c|c|c|c|}
\hline \multirow{2}{*}{ No. } & \multirow{2}{*}{ Nama Fungsi } & \multicolumn{2}{|c|}{ Valid } \\
\hline & & Berhasil & Gagal \\
\hline \multirow[t]{5}{*}{1.} & Login & & \\
\hline & $\begin{array}{l}\text { Kasus dan Hasil Uji } \\
\text { Coba (Data Benar) }\end{array}$ & & \\
\hline & $\begin{array}{l}\text { Username dan password } \\
\text { benar }\end{array}$ & 3 & \\
\hline & $\begin{array}{l}\text { Kasus dan Hasil Uji } \\
\text { Coba (Data Salah) }\end{array}$ & & \\
\hline & $\begin{array}{l}\text { Username dan password } \\
\text { salah }\end{array}$ & 3 & \\
\hline \multirow[t]{13}{*}{2.} & Data Master & & \\
\hline & Data Jenis Tahanan & & \\
\hline & $\begin{array}{l}\text { Kasus dan Hasil Uji } \\
\text { Coba (Data Benar) }\end{array}$ & & \\
\hline & Input Data & 3 & \\
\hline & Edit Data & 3 & \\
\hline & $\begin{array}{ll}\text { Kasus dan Hasil Uji } \\
\text { Coba (Data Salah) }\end{array}$ & & \\
\hline & Input Data & 3 & \\
\hline & Edit Data & 3 & \\
\hline & Data Pasal & & \\
\hline & $\begin{array}{l}\text { Kasus dan Hasil Uji } \\
\text { Coba (Data Benar) }\end{array}$ & & \\
\hline & Input Data & 3 & \\
\hline & Edit Data & 3 & \\
\hline & $\begin{array}{l}\text { Kasus dan Hasil Uji } \\
\text { Coba (Data Salah) }\end{array}$ & & \\
\hline
\end{tabular}


Vol.2 No.1, Agustus 2019

\begin{tabular}{|c|c|c|}
\hline & $\begin{array}{l}\text { Input Data } \\
\text { Edit Data }\end{array}$ & $\begin{array}{l}3 \\
3\end{array}$ \\
\hline & Data Penerima & \\
\hline & $\begin{array}{l}\text { Kasus dan Hasil Uji } \\
\text { Coba (Data Benar) }\end{array}$ & \\
\hline & Input Data & 3 \\
\hline & Edit Data & 3 \\
\hline & $\begin{array}{l}\text { Kasus dan Hasil Uji } \\
\text { Coba (Data Salah) }\end{array}$ & \\
\hline & Input Data & 3 \\
\hline & Edit Data & 3 \\
\hline & Data Rujukan & \\
\hline & $\begin{array}{l}\text { Kasus dan Hasil Uji } \\
\text { Coba (Data Benar) }\end{array}$ & \\
\hline & Input Data & 3 \\
\hline & Edit Data & 3 \\
\hline & $\begin{array}{l}\text { Kasus dan Hasil Uji } \\
\text { Coba (Data Salah) }\end{array}$ & \\
\hline & Input Data & 3 \\
\hline & Edit Data & 3 \\
\hline & Data Jabatan & \\
\hline & $\begin{array}{l}\text { Kasus dan Hasil Uji } \\
\text { Coba (Data Benar) }\end{array}$ & \\
\hline & Input Data & 3 \\
\hline & Edit Data & 3 \\
\hline & $\begin{array}{l}\text { Kasus dan Hasil Uji } \\
\text { Coba (Data Salah) }\end{array}$ & \\
\hline & Input Data & 3 \\
\hline & Edit Data & 3 \\
\hline 3. & Data Tahanan & \\
\hline & $\begin{array}{l}\text { Kasus dan Hasil Uji } \\
\text { Coba (Data Benar) }\end{array}$ & \\
\hline & Input Data & 3 \\
\hline & Edit Data & 3 \\
\hline & $\begin{array}{l}\text { Kasus dan Hasil Uji } \\
\text { Coba (Data Salah) }\end{array}$ & \\
\hline & Input Data & 3 \\
\hline & Edit Data & 3 \\
\hline 4. & Data Barang Bukti & \\
\hline & $\begin{array}{l}\text { Kasus dan Hasil Uji } \\
\text { Coba (Data Benar) }\end{array}$ & \\
\hline & Input Data & 3 \\
\hline & Edit Data & 3 \\
\hline & $\begin{array}{l}\text { Kasus dan Hasil Uji } \\
\text { Coba (Data Salah) }\end{array}$ & \\
\hline & Input Data & 3 \\
\hline & Edit Data & 3 \\
\hline 5. & $\begin{array}{l}\text { Data Rincian Barang } \\
\text { Bukti }\end{array}$ & \\
\hline & $\begin{array}{l}\text { Kasus dan Hasil Uji } \\
\text { Coba (Data Benar) }\end{array}$ & \\
\hline & Input Data & 3 \\
\hline & Edit Data & 3 \\
\hline & Kasus dan Hasil Uji & \\
\hline
\end{tabular}

\begin{tabular}{|c|c|c|}
\hline & Coba (Data Salah) & \\
\hline & Input Data & 3 \\
\hline & Edit Data & 3 \\
\hline \multirow[t]{10}{*}{6.} & $\begin{array}{l}\text { Tindak } \\
\text { Tahanan }\end{array}$ & \\
\hline & $\begin{array}{l}\text { Kasus dan Hasil Uji } \\
\text { Coba (Data Benar) }\end{array}$ & \\
\hline & $\begin{array}{ll}\text { Membuat } & \text { Pengajuan } \\
\text { Pengeluaran } & \end{array}$ & 3 \\
\hline & $\begin{array}{l}\text { Kasus dan Hasil Uji } \\
\text { Coba (Data Salah) }\end{array}$ & \\
\hline & $\begin{array}{ll}\text { Membuat } & \text { Pengajuan } \\
\text { Pengeluaran } & \\
\end{array}$ & 3 \\
\hline & $\begin{array}{l}\text { Pengembalian Barang } \\
\text { Bukti }\end{array}$ & \\
\hline & $\begin{array}{l}\text { Kasus dan Hasil Uji } \\
\text { Coba (Data Benar) }\end{array}$ & \\
\hline & $\begin{array}{l}\text { Pengajuan } \\
\text { Pengembalian Barang } \\
\text { Bukti }\end{array}$ & 3 \\
\hline & $\begin{array}{l}\text { Kasus dan Hasil Uji } \\
\text { Coba (Data Salah) }\end{array}$ & \\
\hline & $\begin{array}{l}\text { Pengajuan } \\
\text { Pengembalian Barang } \\
\text { Bukti }\end{array}$ & 3 \\
\hline \multirow[t]{5}{*}{8.} & $\begin{array}{l}\text { Pemusnahan Barang } \\
\text { Bukti }\end{array}$ & \\
\hline & $\begin{array}{l}\text { Kasus dan Hasil Uji } \\
\text { Coba (Data Benar) }\end{array}$ & \\
\hline & $\begin{array}{l}\text { Pengajuan Pemusnahan } \\
\text { Barang Bukti }\end{array}$ & 3 \\
\hline & $\begin{array}{l}\text { Kasus dan Hasil Uji } \\
\text { Coba (Data Salah) }\end{array}$ & \\
\hline & $\begin{array}{l}\text { Pengajuan Pemusnahan } \\
\text { Barang Bukti }\end{array}$ & 3 \\
\hline \multirow[t]{3}{*}{9.} & $\begin{array}{l}\text { Validasi Tahanan dan } \\
\text { Barang Bukti }\end{array}$ & \\
\hline & Terima Validasi & 3 \\
\hline & Tolak Validasi & 3 \\
\hline \multirow[t]{3}{*}{10.} & $\begin{array}{l}\text { Validasi Pengeluaran } \\
\text { Tahanan }\end{array}$ & \\
\hline & Terima Validasi & 3 \\
\hline & Tolak Validasi & 3 \\
\hline \multirow[t]{3}{*}{11.} & $\begin{array}{l}\text { Validasi Pengembalian } \\
\text { Barang Bukti }\end{array}$ & \\
\hline & Terima Validasi & 3 \\
\hline & Tolak Validasi & 3 \\
\hline \multirow[t]{3}{*}{12.} & $\begin{array}{l}\text { Validasi Pemusnahan } \\
\text { Barang Bukti }\end{array}$ & \\
\hline & Terima Validasi & 3 \\
\hline & Tolak Validasi & 3 \\
\hline \multirow[t]{2}{*}{13.} & $\begin{array}{l}\text { Laporan } \\
\text { Masuk }\end{array}$ & \\
\hline & Melihat & 3 \\
\hline
\end{tabular}


Vol.2 No.1, Agustus 2019

\begin{tabular}{|c|c|c|}
\hline & berdasarkan period & \\
\hline \multirow[t]{2}{*}{14.} & $\begin{array}{l}\text { Laporan } \\
\text { Keluar }\end{array}$ & \\
\hline & $\begin{array}{l}\text { Melihat laporan } \\
\text { berdasarkan period }\end{array}$ & 3 \\
\hline \multirow[t]{2}{*}{15.} & Laporan Barang Bukti & \\
\hline & $\begin{array}{l}\text { Melihat laporan } \\
\text { berdasarkan period }\end{array}$ & 3 \\
\hline \multirow[t]{6}{*}{16.} & $\begin{array}{l}\text { Kasus dan Hasil Uji } \\
\text { Coba (Data Benar) }\end{array}$ & \\
\hline & Input Data & 3 \\
\hline & Edit Data & 3 \\
\hline & $\begin{array}{l}\text { Kasus dan Hasil Uji } \\
\text { Coba (Data Salah) }\end{array}$ & \\
\hline & Input Data & 3 \\
\hline & Edit Data & 3 \\
\hline
\end{tabular}

Dari hasil pengujian diatas, maka dapat dinyatakan bahwa semua fungsi telah berjalan dengan baik secara optimal dan data yang ditampilkan valid.

\section{KESIMPULAN}

Berdasarkan pembahasan yang telah diuraikan sebelumnya, Sistem informasi administrasi tahanan dan barang bukti ini berhasil dibangun menggunakan model prototype yang terdiri atas 5 tahapan yaitu: 1) Communication yang didalamnya mencakup analisa sistem yang sedang berjalan, identifikasi permasalahan yang terjadi serta menganalisa kebutuhan sistem. 2) Quick Plan, mencakup penjelasan mengenai pengguna aplikasi serta memberikan gambaran mengenai sistem yang diusulkan. 3) Modeling Quick Design, mencakup rancangan design model sistem dengan menggunakan UML, merancang ERD serta merancang struktur menu. 4) Contruction of Prototype, mencakup pendefinisian rancangan UML kedalam bentuk kode pemrograman menggunakan bahasa pemrograman PHP dengan framework Laravel serta mendefinisikan ERD kedalam bentuk skema database. 5) Deployment Delivery and Feedback, mencakup pengujian sistem yang pada penelitian ini menggunakan black box testing. Pengujian menggunakan black box testing pada sistem ini mendapatkan hasil yang optimal dan valid karena setiap skenario uji yang diberikan kepada tester memberikan hasil bahwa fungsi tersebut telah berjalan sesuai dengan apa yang diharapkan.

\section{REFERENSI}

Mulyani, S. 2016. Metode Analisis dan Perancangan Sistem. Abdi Sistematika: Bandung.

Mustaqbal, M. S., Firdaus, R. F., \& Rahmadi, H. 2015. Pengujian Aplikasi Menggunakan Black Box Testing Boundary Value Analysis, I(3), 34. Jurnal Ilmiah Teknologi Informasi Terapan: Bandung.

Pressman, S. R., and Maxim, R.B. 2015. Software Engineering: A Practioner's Approach. McGraw-Hill Education: New York.

Sabale, R. G., and Dani, A. R. 2012. Comparative Study of Prototype Model For Software Engineering With System Development Life Cycle. IOSRJEN: India.

Simarmata, J. (2010). Rekayasa Perangkat Lunak. ANDI OFFSET: Yogyakarta 